\title{
低速域における乗り上がり脱線防止のための一提案*
}

\author{
永 瀬 和 彦*1, 橋 弘 矩*2
}

\section{A Proposal for the Preventive Method for the Wheel Climb Derailment}

\author{
Kazuhiko NAGASE*3 and Hironori HASHI \\ ${ }^{* 3}$ Office of Industry-University Collaborations, Kanazawa Institute of Technology, \\ 7-1 Ougiga-oka, No-no-ichimachi, Ishikawa-gun, Ishikawa, 921-8501 Japan
}

\begin{abstract}
The friction coefficient $\mu$ on the contact point position between a wheel flange and a rail is said to seriously affect on the occurrence of the wheel-climb derailment. However, the method to quantitatively and exactly evaluate the $\mu$ has not suggested until to the present. The authors proposed a method to easily and exactly evaluate the value, and made it clear by an experiment, employing a $1 / 5$ scale model track and model truck. The result obtained through the experiment indicates that the value on dry rails has a similarity with that of the adhesion coefficient, and that the dry rail on the main line keeps the value at high level. Using the $\mu$ value obtained by the studies, the risk of the wheel-climb derailment was evaluated. As the result of the evaluation, they found that higher $\mu$ value than the conventionally used one should be introduced for the risk evaluation of the derailment, and that very short term lateral force below $60 \mathrm{~ms}$ should be observed on the steep curvatures.
\end{abstract}

Key Words: Railway, Wheel, Rail, Derailment, Coefficient of Friction

1. は じめに

低速で急曲線や番数の小さい分岐器を通過する際に 発生する「乗り上がり脱線」は, 外軌側の車輪フラン ジ部がレール側面と接触し，この接触点を中心に車輪 が乗り上がる現象である。著者らは $1 / 5$ 縮尺模型を使 った実験で, 従前不明とされた車輪がレールに乗り上 がる際のレールと車輪との接触点位置を明らかに し(1), 当該接触点を中心に車輪がレールに乗り上がる 量を理論的に求める方法(以下，この方法で求めた值 を「理論乗り上がり量」という)を提案した(2). 次い で, この方法で求めた「理論乗り上がり量」と「車輪 が実際にせり上がった量」との差から車輪が「レール に乗り上がる瞬間」および「レールから滑り下がる瞬 間」, すなわち，「臨界脱線状態」に陥った瞬間または その状態が解消した瞬間を特定した.さらに, この時 点における車輪とレールとの接触点における力の釣合 いから, 測定が至難とされたレール・車輪間の摩擦係

* 原稿受付 2008 年 1 月 23 日.

*1 正員, フェロー, 金沢工業大学産学連携窒(画921-8501 石川 県石川郡野々市町扇が丘 7-1).

*2 正員, 中村留精密工業 (株) (焉 920-2195 白山市熱野町口 15) [前：金沢工業大学大学院工学研究科].

E-mail : nagase@neptune.kanazawa-it.ac.jp

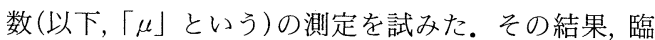
界脱線状態のもとにおける $\mu$ は粘着係数とほぼ同じ 傾向にあることを明らかにした ${ }^{(3)}$.

本研究では前記の一連の研究(以下「先の研究」と いう)で得た知見と最近発生した脱線事故の原因調査 報告などを踏まえ, 乗り上がり脱線について新たな視 点から検討を試みた. 具体的には脱線の発生に支配的 な影響をもつとされながらいまだ十分に解明されてい るとはいえない本線上における 従前の研究で得た知見も交えて值の推定を試みた.さ らに，その方法で得た值を用いて，脱線が起こりうる 可能性などについて検討した。

その結果, 従前は等閑視されているケースが多かっ た短小時間の著大な脱線係数も, 脱線に結びつく可能 性があることなどを明らかにする，次いで，このよう な現象によって脱線が起きる事態を防ぐための対策を 提言する.

\section{2. 瞬時の著大脱線係数が脱線に及ばす影響}

$2 \cdot 1$ 従前の脱線係数のしきい值 日本の鉄道で 従前から広く使われてきたフランジ角 $60^{\circ}$ 程度の車輪 では, $\mu$ が 0.3 程度以上の值をとった場合には脱線係 数が 0.8 を上回るとナダール限界を超える可能性があ 
る.このため, 乗り上がり脱線の危険性を定量評価す る指標として, 曲線通過時には外軌側の車輪を「脱線 係数 0.8 以下」に保持すべきとの基準が賞用されてい る.しかし, ナダール限界をどの程度の長さ (時間)上 回ると脱線が起きるか, さらには, ナダール限界に深 く関わる $\mu$ については必ずしも十分な解明が行われ ているとはいえない.

\section{$2 \cdot 2$ 瞬時の著大脱線係数に関わる問題 ところ} で, 周知のように脱線係数は横圧を輪重で除した值で あり,これらは互いに独立して輪軸に作用する。した がって, 同じ横圧が持続した状態のもとで瞬時の輪重 抜けが発生すれば, 輪重抜けが起きた側の車輪の脱線 係数はその場に限って急増する。一方, 輪重抜けのな い場合も，トングレールに入射角がある分岐器 ${ }^{(4)}$ およ び「角折れ」のある継目などを通過する際にも, 瞬時 に著大横圧が発生して高い脱線係数が短小時間観測さ れる場合がある.

このような瞬時の輪重抜けや高い横圧の発生によっ て短小時間生じる高い脱線係数 (以下, これを「短小 著大脱線係数」という)の対策として, 昭和 38 年に貨 物列車の脱線により 160 名が死亡した「鶴見事故」を 受けて国鉄が制定した「脱線係数の運用基準」(5)があ る。その要旨は, ボギー車については 0.8 程度以上の 高い脱線係数が $50 \mathrm{~ms}$ 以上持続する状況が発生する 頻度は 1 分岐器通過ごとまたは $500 \mathrm{~m}$ 走行するごと に 1 回以下を当面の安全限度とし, 将来は脱線係数の 限度を 0.7 以下に引き下げるというものである.しか し，このような持続時間が短い横圧については従前は 飛び上がり脱線の範ちゅうに属する問題として論じら れる場合が多く, 乗り上がり脱線に関わる問題として 十分な議論がなされているとはいえない.

その後, 平成 12 年に地下鉄日比谷線で起きた脱線 事故にかんがみ，乗り上がり脱線防止のための対策と

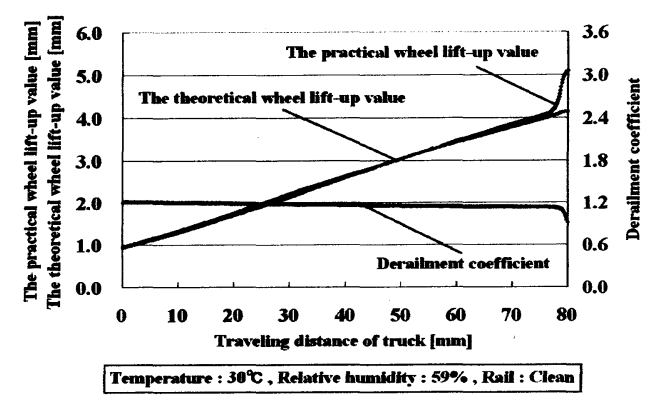

Fig. 1 Comparison of the theoretical wheel lift-up value and the practical wheel lift-up value (atmosphere temp. : $21^{\circ} \mathrm{C}$, humidity : $36 \%$ )
し推定脱線係数比の守るべき目安を 1.2 以下とし, 静 止輪重比の限度は 0.9 に留めることが望ましい旨の国 の通達がなされている(6).

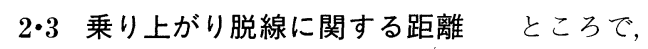
車両が臨界脱線状態になってから脱線に至るまでの時 間はどの程度になるのであろうか. それについて著者 らが行った実験で得られた結果を図 1 に示す。

図 1 は, 著者らが従前から本研究に継続使用中の曲 線半径 $100 \mathrm{~m}, 50 \mathrm{~N}$ レール使用の軌道と軸距 $2.0 \mathrm{~m}$ の二軸台車を $1 / 5$ スケールに縮尺した模型の実験装置 で行った脱線実験の結果を示す(7). 車輪形状はフラン ジ角 $57.5^{\circ}$ でこう配 $1 / 20$ の円すい踏面, レールは乾 燥状態, 脱線係数は約 1.2 , 車輪がレールに乗り上が ってから脱線に至るまでの平均的なアタック角は約 $1.3^{\circ}$ 程度である.

図 1 の縦第 1 軸には理論乗り上がり量とレール踏面 からの実測せり上がり量を, 縦第 2 軸には脱線係数を, 横軸には台車進行距離を示す.

図示のとおり, 車輪は図左端で臨界脱線状態に達し, その時点から乗り上がりを継続して脱線するまでの距 離(以下,「脱線に要する距離」という) は $80 \mathrm{~mm}$ 程 度,これを実スケールに換算した距離は約 $0.4 \mathrm{~m}$ にす ぎない.この曲線とほぼ同じ 8 番の片開き分岐器上を 制限速度 $25 \mathrm{~km} / \mathrm{h}$ で走行に要する時間はわずか 58 ms 程度である.フランジ角度がより大きい場合には， 後述するようにレールと車輪の接触点位置と車輪中心 との距離が増大するので(8), 車輪の単位回転量当たり の乗り上がり量も増大し, 脱線に要する距離や時間も 短縮されることになる.

$2 \cdot 4$ 短小著大脱線係数発生の実態 前記の事実 を踏まえれば，現在は滑り上がり脱線または飛び上が り脱線の範ちゅうに属する現象とみなされているため に比較的等閑視されている $50 \mathrm{~ms}$ 程度またはそれ以 下の短小著大脱線係数についても, より厳格な監理が 必要ということになる。しかし, このような瞬時の横 圧を車両側で計測するのは容易ではなく，その必要が ある場合には地上で測定するケースが多い.

地上で実測した短小著大脱線係数について著者が個 人的に得た情報の中には，通常状態に整備された軸距 $2 \mathrm{~m}$ 程度の台車を装架した車両がトングレールに入射 角のある 8 番片開き分岐器に制限速度を遵守して通過 した際に, 1.0 を大幅に超える脱線係数が実測された 事例が少なからず存在する。しかし，これらは残念な がら鉄道内部の情報に留まるものである，最近，公に されたこれに関わる数少ないデー夕に, 意図的に著大 な輪重差を設けて急曲線を通過させたときに, 脱線係 
数が著大な值をとることを確認した貴重な本線実験(9) が存在する.これとは別に荷重満載のコンテナ貨車が 12 番片開き分岐器の分岐側を対向して制限速度上限 で通過中に，外軌側車輪に通常よりやや高い横圧が発 生した状態のもとでローリングによる顕著な輪重抜け が重畳して脱線係数が 2.0 に近い值になったことなど が原因で乗り上がり脱線が起きたとされた事例があ $ろ^{(10)}$.

別の原因による事例に, レールに波状磨耗がある箇 所を高速走行中の新幹線電車が約 $1 \mathrm{~m}$ 進行する間に 輪重がほぼ 0 から静止輪重の 2 倍程度に激変したケー スがある(11). 一方, 著者らの研究によれば, 清浄なレ ールと車輪との接触面における接触抵抗は通常の接触 面圧の範囲では，当該接触面圧に応じて変化する ${ }^{(12)}$. そこで, 実際の車輪に生じているのと同程度のわずか な偏心を意図的に付与した $1 / 5$ 縮尺の模型輪軸を軌道 回路上で低速走行させ, 接触抵抗の変化から輪重変動 の状況を測定した. その結果, 車輪の偏心は, たとえ 低速走行時でも顕著な輪重変動を引き起こすことを明 らかにした ${ }^{(13)}$.

これらの状況から類推すれば, 実際の急曲線上では 瞬時の著大な輪重抜けに伴う短小著大脱線係数がかな りの頻度で発生している可能性は否定できない.

\section{$2 \cdot 5$ 輪重抜けが短小著大脱線係数に及ぼす影響}

前記の事実を踏まえれば，乗り上がり脱線防止策を 押し進めるに際しては，まず短小著大脱線係数と瞬時 の著大な輪重抜けの実態把握が必要となるが，これを 行うのは容易でない. そこで, フランジ角 $57.5^{\circ}$, 静 止輪重比 1 の輪軸に一定の横圧が持続して作用した状 態のもとで瞬時の輪重抜けが起きて短小著大脱線係数 が発生する事態となっても, ナダール限界を超えない ために事前に保つべき脱線係数の限界と $\mu$ との関係 を図 2 に示す.

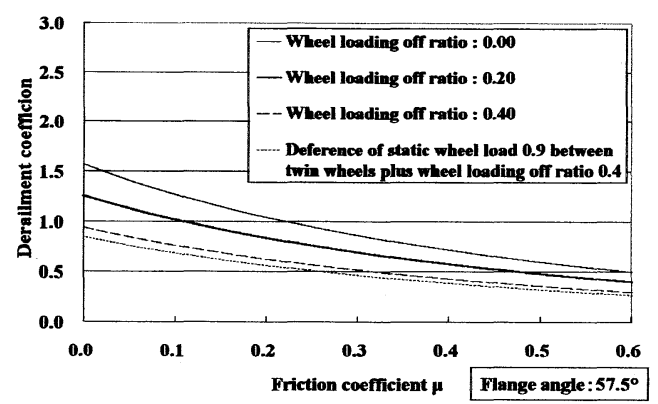

Fig. 2 Relationship between $\mu$ and the limit of the derailment coefficient under various wheels offloading ratio (wheel flange angle $57.5^{\circ}$ )
図 2 の実細線は輪重減少率 0 のもとで保つべきナダ ール限界を示す. 図示のように $\mu=0.3$ のときの脱線 係数限界值は 0.8 を少し上回る.この值は日本で賞用 されている.その下の実太線は輪重減少率が 0.2 , さ らにその下の破線は減少率 0.4 の場合の限界を示す。 図示のごとく, 輪重隇少率 0.4 の場合には $\mu=0.3$ の もとで脱線係数の限界は約 0.5 に低下する.次に, 静 止輪重比が規制限界 ${ }^{(6)}$ である 0.9 の輪軸に輪重減少 率 0.4 なる輪重抜けが重畳して起きた場合の脱線係数 の限界を図中に鎖線で示す.この場合には $\mu=0.3$ 程 度で限界值は 0.4 に近い程度にまで低下する。

問題は静止輪重比 0.9 程度の車両は少なからず実在 し(14)(15), さらに減少率が 0.4 程度の輪重抜けは実際 に起きていることにある(10).この状態が $60 \mathrm{~ms}$ 程度 以上持続する状況のもとで $\mu$ が 0.3 を上回る值をと れば，フランジ角 $57.5^{\circ}$ の輪軸では乗り上がり脱線が 起きる可能性が否定できないことになる.このような 実情および曲線での輪重変動の発生状況などを踏まえ 平成 16 年 6 月には, 前述した推定脱線係数比が目 安(6)である 1.2 を上回った場合, つまり, 著大な脱線 係数が存在する場合にはフランジ角度 $60^{\circ}$ 程度の輪軸 では半径 $100 \mathrm{~m}$ の曲線上での輪重変動率を約 0.3 程 度以下に保つことを目安とすべき旨の国の通達が出さ れている(16). しかし, この通達に沿って脱線係数を算 出する際に採用す心゙き $\mu$ の值については, 不明な点が 多いこともあって具体的な值は示されておらず, 輪重 減少率の持続時間の限度についても規定されていな い. したがって, 今後, 乗り上がり脱線対策をより深 度化するためには, 著大脱線係数持続時間の把握およ び $\mu$ の実態把握が不可欠となる.

\section{3. レール・車輪間の摩擦係数 $\mu$ 把握の方法}

乗り上がり脱線に関わる問題で摩擦係数 $\mu$ を論じ るに際しては, 本来はレール・車輪間の静的な力関係 や $\mu$ に関わる現象だけでなく, 輪軸の回転に伴うモー メントや車輪とレールとの微小なすべり(いわゆる 「クリープ」)についても考慮する必要がある.しかし， 乗り上がり脱線の多くはモーメントやクリープを無視 できる領域で起きている。 そこで, 本研究ではこれら を無視しうるものとみなし, 以下には $\mu$ に関わる問題 に焦点を当てて論じてみよう.

\section{$3 \cdot 1$ 臨界脱線状態のもとにおける摩擦係数 $\mu$}

乗り上がり脱線は $\mu$ が高い場合に起きやすいとさ れるが，どのような場所や状況のもとでそのような状 態になるのかは明らかではない. 限られた具体的事例 として, 車輪を削正した直後の踏面が粗い車両は, $\mu$ 
が高いと想定されるために脱線が起きやすいとさ れ(17)(18), 最近は海外でも同じ認識にある(19).

本線上での $\mu$ を求めるためには実車による実験を 必要とするが, これには危険を伴うため実施は困難と され, 車輪削正直後の $\mu$ についてすらも実測した事例 はない. 著者らは先の研究第 4 報(3)で, 新たに提案し た手法により模型の実験装置を使い, 臨界脱線状態の もとにおけるレールと車輪との接触点が清浄で乾燥し た状態と, 油塗布した状態のもとにある $\mu$ にいて速 度との関係を調べた. その結果の一部を図 3 に示す. 図中の白抜きマークは車輪が乗り上がりを開始した時 点の $\mu$ を示し, 塗りつぶしマークは車輪が臨界脱線状 態を脱して滑り下がりを開始した時点のそれを示す. 図示の通り, 双方の值に差異は認められず，レールが 清浄状態時の $\mu$ は 0.32 から 0.25 程度の値をとり, 顕 著な速度依存性も認められない, 一方, 油塗布状態に おける 速度の低い領域での值は高い領域に比べ值が大幅に高 くなっていることに特徴がある.

$3 \cdot 2$ 脱線と粘着とのメカニズムの類似性 先の 研究第 1 報 ${ }^{(20)}$ で脱線実験を実施した際に, これに合 わせてレール踏面を脱線実験と同じ状態とし, さらに 速度も同じ状態で $1 / 5$ スケールの粘着台車 ${ }^{(21)}$ を走ら せ粘着係数 (以下, 「 $\left.\mu^{\prime}\right\rfloor$ とう) を実測した. そのと きに得た台車走行速度 $\mu^{\prime}$ との関係を図 4 に示す。

得た粘着係数 $\mu^{\prime}$ と先の研究第 4 報で得た摩擦係数 $\mu$ とを比べると, レール清浄時の $\mu$ および $\mu^{\prime}$ は值も ほぼ同じであり, 速度依存性が低いことにも類似性が 認められる. 一方, 油塗布した状態での $\mu^{\prime}$ は乾燥ま たは清浄レールのそれより低い值をとり, 先の研究第 4 報で得た油塗布時の $\mu$ と比べ值は高く, 強い速度依 存性および温度依存性が認められる. 図 4 の実験にお いて, レール踏面と車輪踏面間の接触点の面圧は通勤 電車のそれと同じ程度の值であったのに対し, 図 3 に

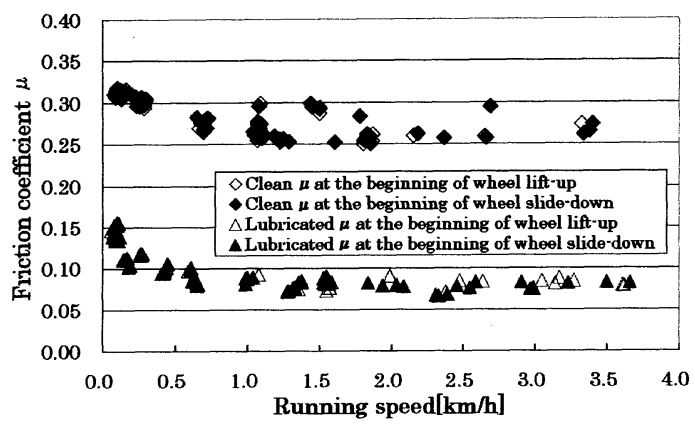

Fig. 3 Relationship between running speed and a friction coefficient
示す第 4 報で行った $\mu$ を求める実験での接触面圧は 実車の 3 割程度と低かったことも差異の一因と考えら れる(22).

ここで, 臨界脱線状態のもとにおけるレールと車輪 との接触点の状態について考えてみる. 走行中の車両 が臨界脱線状態に陷ると, 車輪フランジ部のレールと の接触点における摩擦力の増大によって, 車輪はレー ル側面に固着し，あたかもその点に引っ掛かったよう な状態となって, その点を起点として乗り上がりを開 始する.しかし, 乗り上がりを開始した時点では車輪 はまだレール側面に完全に固着した状態になってはお らず, 若干の滑り下がりが起きている状態にあると推 定される.このため, この時点でレールと車輪の接触 点の場は動摩擦が支配していると考えられる。一方, 臨界脱線状態を脱した時点とは, それまでは接触点に おりる摩擦力によって車輪がレール側面に固着して滑 り下がりが阻止されていた状態から, 摩擦力の減少に よって車輪が滑り下がりを開始する瞬間である.した がって, この時点とは, それまでの接触点における静 摩擦の支配が解消される時点でもあると推定される.

ゆえに著者らは車輪が乗り上がりを開始する時点の 接触の場は動摩擦が支配し, 滑り下がりを開始した時 点の接触の場は静摩擦が支配すると考え, 両者は異な つた值になると予想した．実験の結果は著者らの予想 を覆し, 図 3 に示すとおり両者の間に差異を認めるこ とはできなかった。車輪が乗り上がりの状況を脱し, 滑り下がりを開始する瞬間であっても車輪が転動して いる限りは接触点で車輪は絶えず旋回運動をしてお り, 完全な静止摩擦が支配する場にはないためである と考えた。

脱線に関わる既報 ${ }^{(3)(20)}$ で述べた実験を通じ, 摩擦係 数 $\mu$ と粘着係数 $\mu^{\prime}$ とは極めて類似した傾向をもつこ

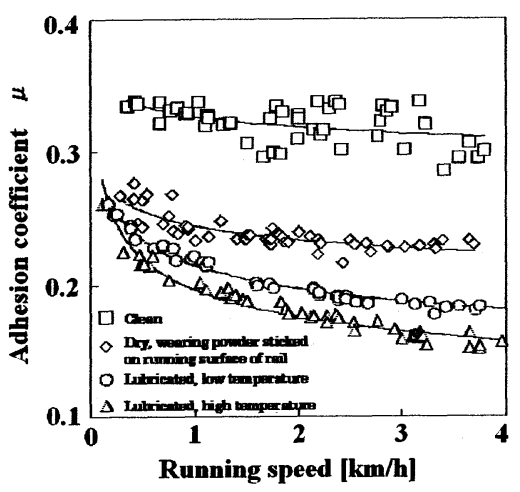

Fig. 4 Relationship between running speed and adhesion 
とが明らかになった。「乗り上がり脱線」と「粘着」 という二つの異なる現象が起きる接触点の場のメカニ ズムを見ると, 前者はレール側面の接触点で車輪が旋 回しながらその点が前方向に移動し, 後者は車輪がレ ール踏面でレール長手方向に極めて微小な滑りを生じ させながらレール踏面を転動接触している。つまり， 両者はいずれも同一の部材が旋回または微小な滑りを 合わせ生じさせながら接触の場が移動する点に類似性 がある。このように双方の接触の場に類似した現象が 存在することが, 值自体に類似性をもつ一因であると 推定した.

\section{$3 \cdot 3$ 模型軌道における粘着係数 乗り上がり脱} 線発生の危険性を定量評価するためには $\mu$ の実態を 知ることが不可欠であるが，本線上でこれを実測する のは容易でない.したがって, 現時点では $\mu$ を得るた めには別途の方法でこの值を推定する以外に適当な手 法が見当たらない.

著者らが先の研究第 1 報の実験で用いた $1 / 5$ スケー ル模型の粘着台車は $15 \mathrm{~km} / \mathrm{h}$ 程度までの速度域で, レール踏面が「清浄」および「湿潤」のもとでの $\mu^{\prime}$ 取得のための実験を行っている。しかし，これらの実 験では，レール踏面に介在する夾雑物などの因子が $\mu$ に及ぼす影響を評価していない。そこで，レール踏面 に介在する $\mu^{\prime}$ に関わる夾雑物の代表的な因子である レールと車輪との摩擦により発生する摩耗粉が $\mu^{\prime} に$ 及ぼす影響の評価を行った。

この研究では実験を簡易にするために, 実験用軌道 のレール踏面粗さを JIS B 0601 に定める中心線平均 粗さで $3.3 \mu \mathrm{m}$, 粘着台車の車輪踏面粗さを $1.3 \mu \mathrm{m}$ に

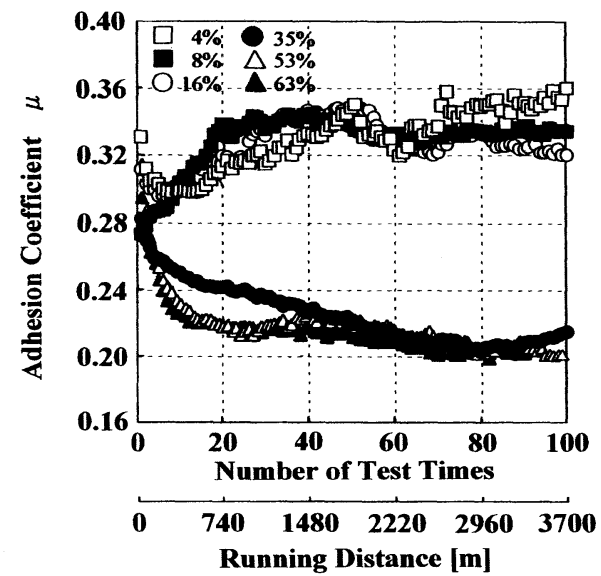

Fig. 5 Changing of adhesion according to the running distance of the test truck under various humidity around the running surface of rail (atmosphere temp. : $28^{\circ} \mathrm{C}$ )
仕上げたうえで清拭し, 粘着台車を長さ約 $20 \mathrm{~m}$ の実 験軌道を連続走行させて $\mu^{\prime}$ を測定した。このような 方法をとれば, 粘着台車の滑り軸がレール上を滑り走 行することによって発生しレール踏面に堆積する金属 磨耗粉について，张に及ぼす影響を評価できるからで ある.さらに, レール踏面付近の大気はレール温度と 同じとみなし，レール温度を制御することによってレ 一ル付近の大気の相対湿度も多様に変化させた ${ }^{(23)}$. 実験結果の一例を図 5 に示す.

図示のとおり $\mu^{\prime}$ はレール付近の大気相対湿度抢よ び実験台車の走行距離の増大(すなわち，滑り軸の滑 り走行によって発生する金属摩耗粉の増大)に応じ変 化している。この実験を通じ, 実験開始直後のレール 清浄時の $\mu^{\prime}$ の值は先の研究第 1 報で得た值とほぼ同 じであること，そして，レールが極端に乾燥した状態 では，レールと車輪との金属磨耗分が蓄積された状態 で $\mu^{\prime}$ は極めて高い值をとり, その值は 0.35 程度に達 することなどがわかった。

$3 \cdot 4$ 本線上における粘着係数 以上は模型にお ける実験の結果である，著者らは過去に本線上の粘着 係数 $\mu^{\prime}$ を連続取得することを意図して粘着台車を実 車に装架して走行させた．当該台車は製作直後に試験 専用客車に装架され，国鉄大宮工場の構内で粘着係数 測定用輪軸の滑り率の適值を模索するための実験を行 った。その結果, 粘着の実態を把握するためには測定 軸の滑り率を $5 \%$ に設定することが最適であるとの結 論を得た(21). これ以降の実験は前述の $1 / 5$ 縮尺の模 型実験用粘着台車を含め, すべてこの滑り率で行われ ている. 当該台車は, その後, 客車, 通勤形電車打よ び粘着台車による粘着実験を行うために特別に改造さ れた粘着測定専用試験電車クヤ471 形などに装架さ れ，各地の国鉄および JR 本線上を走行して $\mu^{\prime}$ を取得 した：走行区間の一例を表 1 に示す.

本線上で行われた粘着係数取得の走行実験では，天 候が同一条件のもとで走行区間の全域にわたり車輪 1 回転ごとに $\mu^{\prime}$ を取得し, その值を速度域別に統計処 理したデータがある.これらのデータのうち, 最も高 い $\mu^{\prime}$ を得た好天時の測定結果の例を示す。図 6 は東 北本線東鷤宮〜小山間の上り線約 $30 \mathrm{~km}$ を冬の昼間, 快晴の日に走行して得たデータである(24). 図 6 の横 軸には $\mu^{\prime} を$, 縦軸には速度を示し, 破線は車輪 1 回転 ごとに 1 回の頻度に測定した $\mu^{\prime}$ を $10 \mathrm{~km} / \mathrm{h}$ ごとの速 度域別に分け，それぞれの速度域における $\mu^{\prime}$ の分布 を横軸の目盛 0.01 を $1 \%$ とした百分率で示したもの である．実線は速度域別の $\mu^{\prime} の$ 平均值を示す.

図 6 を見ると低速度域での $\mu^{\prime}$ は比較的低い。その 
Table 1 The JR main lines investigated adhesion coefficient by the slpping adhesion test truck

\begin{tabular}{|c|c|c|c|c|c|}
\hline \multicolumn{2}{|c|}{ Experimental lines } & \multirow{2}{*}{ Year } & \multirow{2}{*}{ Type of cars } & \multirow{2}{*}{$\begin{array}{c}\text { Axke } \\
\text { wight(kN) }\end{array}$} & \multirow{2}{*}{$\begin{array}{l}\text { Slipping } \\
\text { ratio(\%) }\end{array}$} \\
\hline Name of line & Test section & & & & \\
\hline JNR Ohmiya Workshop & Test line & 1984 & Maya-40 & 80 & $5-15$ \\
\hline Tohhokulne & Ohmiya - Higasi Wasinomiya & 1986 & Maya-41 & 80 & 5 \\
\hline Yamanote-line & the whole line & 1986 & Saha-101 & 70 & 5 \\
\hline Nikko line & the whole line & 1989 & Kuya -471 & 80 & 5 \\
\hline Chikuhi line & Meinohama-Karatsu & 1990 & Kuya -471 & 80 & 5 \\
\hline
\end{tabular}

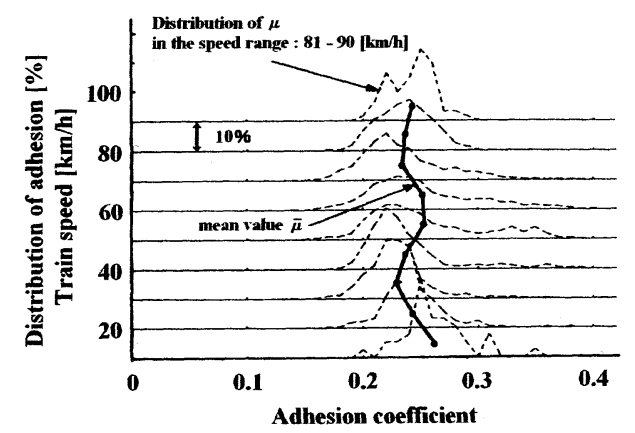

Fig. 6 Distribution and mean value of adhesion for various speed ranges (Tohoku line, daytime, fine)

理由は $\mu^{\prime}$ を低下させるさびが付着した駅構内の側線 レールを低速走行したためである，沿線には踏切，森 林および大規模河川に掛かる橋りょうなどの $\mu^{\prime}$ を局 所的に低下させる諸因子(25) が存在し, 中速域以上の 速度域での低い $\mu$ はこれらの箇所で得ている. 他方, 日当たりが良く, レールが乾燥した高架区間では $\mu^{\prime}$ は 0.40 をやや上回る高い值を得ている.このため, 図 6 に示すとおり $\mu^{\prime}$ は広い範囲にわたっている。し かし， $\mu^{\prime}$ の平均值はほとんどすべての速度域で 0.32 前後の值をとり, 高いところでも 0.35 程度に留まっ ている.

つまり, 本線上の $90 \mathrm{~km} / \mathrm{h}$ 程度までの速度域にお ける高い粘着係数の值は, 模型で得たそれとほぼ一致 した。そして，このような值は本線ではレールが直射 日光で乾燥した状態にある好天時の昼間に得ている. 他方, 模型実験では同じようにレールが乾燥状態にあ り，レール踏面は清浄またはレールと車輪の摩耗によ る金属粉が付着した状態のもとで得ている。つまり， 本線捛よび模型の双方ともに，高い $\mu^{\prime}$ を得た条件は 極めて類似しているのである. 数少ない相違点は, 模 型実験における走行最高速度は $15 \mathrm{~km} / \mathrm{h}$ 程度に留ま ること抢よびレールと車輪の踏面に車輪の滑り走行に よって生じる多量の金属粉が介在するデー夕を含むこ
と, 実車でのこの速度域での $\mu^{\prime}$ は低い数值に留まっ ていることにある.このうち, 金属粉の問題について は, 本線上のレールは模型実験のレールほどに多量で はないが，レールおよび車輪の摩耗による金属粉は付 着しているので, 両者の間に顕著な相違があるわけで はない. 本線上の $\mu^{\prime}$ の值が低速域で低い結果となっ た理由は前述した。

$3 \cdot 5$ 塗油されたレールの摩擦係数 $\boldsymbol{\mu} \mu$ が高い 值をとる乾燥したレール上で乗り上がり脱線が起きや すいことは当然であるとしても, 多くの脱線は急曲線 や番数の小さい分岐器上で起きている.急曲線部分は 「キシリ音」防止またはレールと車輪の損耗防止のた めに, 塗油を行っている鉄道が多く, 分岐器について は不転換事故防止のためにトングレールを支える床板 に多量の油が塗布され，その油がレール踏面までしみ 出している場合が多い.したがって，このような箇所 のレール・車輪間の摩擦係数 $\mu$ は塗油の影響を受け て低いと見られ，脱線の危険性は本来的には低いと思 うべきであろう。

これを裏付けるように, 例えば前述の研究(24) で得 た山手線の品川〜大崎間にある半径 $300 \mathrm{~m}$ の曲線に 置かれた通称「アラジン」と呼ぶ塗油器付近の外軌側 レールの $\mu^{\prime}$ は速度 $60 \mathrm{~km} / \mathrm{h}$ 程度で 0.05 程度であっ たと推定され, 粘着台車が他の線区の同様の地点で得 た值もこれと大きく異ならない值であった。一方, 同 じ粘着台車を用いた研究(24) で東北線乃木駅構内分岐 器上を $22 \mathrm{~km} / \mathrm{h}$ で通過時に, トングレール上で得た $\mu^{\prime}$ は 0.08 程度と推定され, 他の分岐器上での值もこ れに近い值であった。したがって, 油が付着したレー ルの摩擦係数 $\mu$ も粘着係数 $\mu^{\prime}$ と同じく低い值となっ ている可能性が高い.

ところで, 塗油したレールの摩擦係数 $\mu$ につて調 べた結果は, 図 3 に示すように顕著な速度依存性があ り，低速域に限って見れば $\mu$ は決して低くはない。模 型の粘着台車で得た塗油したレール上の粘着係数 $\mu^{\prime}$ も, 図 4 に示すように顕著な速度依存性が見られた。 


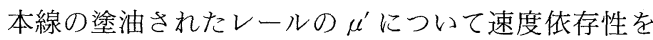
測定した事例はないが，レール・車輪間に油と同じよ うに流体が介在することになる降雨時のレール踏面が

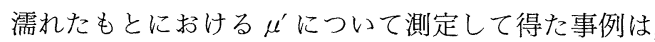
いずれも低速域では高い速度依存性がある(24)(26)。そ の一例として, 日光線の下野大澤〜今市間 $5.7 \mathrm{~km}$ で 降雪時に得た速度域別の粘着係数 $\mu^{\prime}$ の分布を示すデ ー夕(26) を図 6 と同じ方法で表したものを図 7 に示す. 測定日の気象などは図中に示す，図示のように低速域

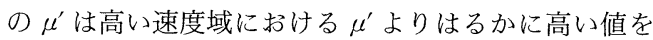
とっている.

平成 12 年に速度 $12 \mathrm{~km} / \mathrm{h}$ で走行中に起きた東京地 下鉄日比谷線脱線事故の曲線半径 $160.1 \mathrm{~m}$ の現場も 手前にはレール塗油器が設置されており ${ }^{(15)}$, 平成 18 年 1 月に神戸電鉄有馬口構内の 8 番片開き分岐器上で 正確な速度は不明ながら駅発車直後の低速走行時に起 きた脱線事故ではトングレール終端部に車輪乗り上が り跡があるとされ，その直後の 2 月に同鉄道で速度 15 $\mathrm{km} / \mathrm{h}$ で同じように 8 番片開き上で起きた脱線では, 油が付着していたと推定されるトングレールを通過後 わずか $3 \mathrm{~m}$ の位置で車輪が乗り上がったとの記録が ある ${ }^{(18)}$. 日比谷線脱線事故で使われた車輪のフラン ジ角度は $60^{\circ}$, 神戸電鉄のそれは $57.2^{\circ}$ であった. 日 比谷線で脱線した車両の輪重差は不明とされたが, 神 戸電鉄で平成 18 年初めに続けて起きた事故のうち, 1 月の事故で最初に脱線した輪軸の静止輪重比は 1.02 , 2 月の事故で最初に脱線した輪軸の静止輪重比は 1.00 であったことが明らかにされている。すると，もし， 脱線現場の $\mu^{\prime}$ の值が過去の研究で本線上の油を塗布 した状態のレール付近で得た前述の $\mu^{\prime}$ とほほ同じ程 度の 0.1 またそれ以下であり,さらに，2 章で述べた 仮定, すなわち, 粘着係数 $\mu^{\prime}$ と摩擦係数 $\mu$ との值が 大きくは異ならないのなら, 神戸電鉄の脱線事故は起

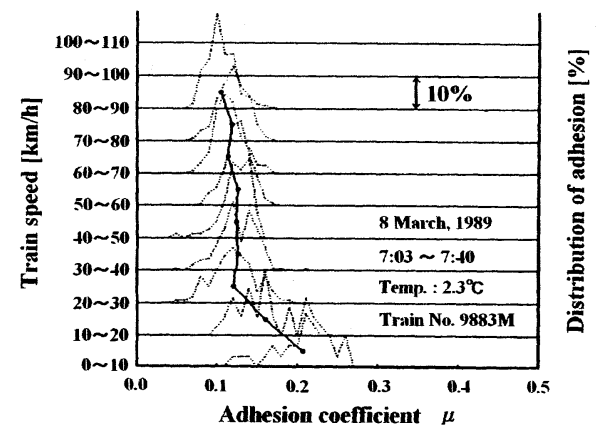

Fig. 7 Distribution and mean value of adhesion for various speed ranges (Nikko line, daytime, snow)
きなかった可能性があるなな゙なら，これらの事故は 分岐器の平面性狂いなどだけでなく，車輪とレールと の摩擦係数の増加も一因との指摘がなされているから である、したがって, 塗油されたレール付近で乗り上 がり脱線が起きている事実は, $15 \mathrm{~km} / \mathrm{h}$ 程度以下の低 速域では塗油されたレールであっても くはないことを示す状況証拠ということもできる.

とはいっても, 塗油されたレールの低速域での $\mu$ の 值がどの程度かの調査は極めて難しい. $\mu$ は前述のよ うにレール温度などに応じて変化する(20)だけでなく， 接触面圧や油の種類などに応じ変化するからであ る ${ }^{(22)}$. 神戸電鉄の 2 件の脱線事故車の車輪踏面は前 述のように研削直後の粗い状態にあったとされ(17)(18), 最近起きた外国での脱線事例も同様のことが指摘され ている(19). 車輪削正直後の踏面が粗い輪軸および油 が付着したレールについて，低速域における 解明は乗り上がり脱線防止のための今後の重要な研究 課題である.

$3 \cdot 6$ 本線上における粘着係数と摩擦係数との類似 性今まで述べたように $1 / 5$ スケール模型の粘着台 車が得た $\mu^{\prime}$ と，同じスケールの軌道上で同じ条件で 脱線実験を実施して得たレールと車輪との接触点にお ける摩擦係数 $\mu$ とは, レールが乾燥し, かつ, 清浄状 態にある場合には，ほぼ同じ値を得ている。また、レ ール踏面に金属摩耗粉が堆積した模型のレールと, 若 干の金属摩耗粉が介在する本線上のレールとは, レー ルが乾燥した状態のもとではほぼ同じ值を得ている。 よって, 臨界脱線状態のもとに扔ける本線上の $\mu$ と $\mu^{\prime}$ とは乾燥レール上では同じ值である可能性が高い. そこで, 本研究では以下のような理由で, 本線上の乾 レールで粘着台車が得た $\mu^{\prime}$ の値を臨界脱線状態のも とにおけるルの值とほほ同じ値とみなして議論を進 めることにした。

（1）先の研究第 4 報で行った実験の過程で，4 $\mathrm{km} / \mathrm{h}$ 程度までの極めて低い速度域で得たレール清浄 時の摩擦係数 $\mu$ と, 同じ条件のレール上で得た粘着係 数 $\mu^{\prime}$ とは，ほほ同じ值を得たこと.

（2）先の研究第 1 報の実験で使用した模型の粘着 台車が $15 \mathrm{~km} / \mathrm{h}$ 程度までの速度域について, レール が乾燥状態で踏面が清浄または金属の摩耗粉を堆積さ せた状態のもとで得た $\mu^{\prime}$ の值と, 実車に装架した粘 着台車が本線で好天時にレール乾燥状態のもとで得た $\mu^{\prime}$ とは，ほぼ同じ值と同じ傾向を示したこと。

（3） $\mu$ と $\mu^{\prime}$ との接触の場は， $4 \cdot 2$ 節で述べたよ うに接触のメカニズムに類似性が見出されること.

（4）本線上の $\mu$ を先の研究の第 4 報で述べた著 
者ら提案の方法で取得するには実車を臨界脱線状態に することが必要で，その実施は極めて困難であるこ と.

（5）したがって，片ついてはいま述べたような 方法で值を推定する以外に現段階では適当な手段が見 出せないこと.

\section{4. 脱線防止対策案}

以上の知見を基に半径 $100 \mathrm{~m}$ 程度の急曲線を主体 とした乗り上がり脱線防止策を述べてみよう.

$4 \cdot 1$ 摩擦係数 $\boldsymbol{\mu}$ 前述のようにナダール限界に 支配的な影響を及ぼすレール・車輪間の摩擦係数 $\mu$ は，直射日光のもとで乾燥状態にあるレールでは現在 広く使われている值である 0.3 より高く, 0.4 程度に 達する可能性がある.よって, ナダール限界を調べる に際してはこの值を使用することが望ましい。なお， レールへの塗油はお打むね $20 \mathrm{~km} / \mathrm{h}$ 程度以上の速度 域で $\mu$ を低下させる効果は認められるが，それ以下の 乗り上がり脱線が多発する速度域での効果については 今後の研究に待つべきものが少なくない.

$4 \cdot 2$ フランジ角の増加の影響 $\quad \mu$ が 0.4 程度の 值をとったとき，フランジ角 $57.5^{\circ}$, 静止輪重差のな い輪軸の限界脱線係数を図 2 から求めると約 0.7 程度 の值となる.さらに，当該輪軸に静止輪重差が 0.1 あ るとき, 減少率 0.4 程度の輪重抜けがこれに重畳して 起きた場合の限界脱線係数は 0.4 程度にまで低下す る.この対策としてフランジ角を増加させ $70^{\circ}$ とした 輪軸について, 静止輪重差抢よび輪重減少率に応じた ナダール限界を図 2 と同様の方法で表したものを図 8 に示す.

$\mu$ が 0.4 をとったとき, 静止輪重差や輪重抜けがな い場合の限界脱線係数を図から求めると約 1.1 程度と なって, フランジ角 $57.5^{\circ}$ のもと比べ限界は大幅に

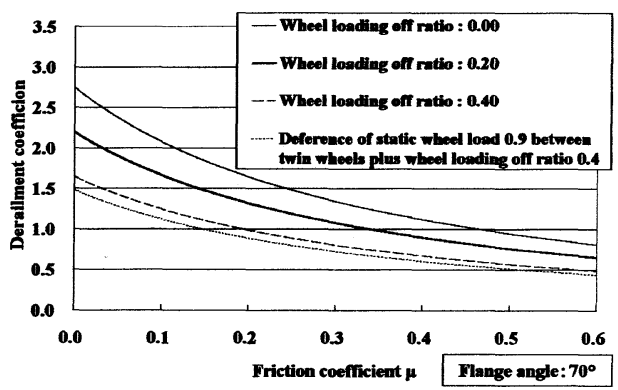

Fig. 8 Relationship between $\mu$ and the limit of the derailment coefficient under various wheel offloading ratio (wheel flange angle $70^{\circ}$ )
上昇する. 静止輪重差が 0.1 あるとき, 減少率 0.4 程 度の輪重抜けが重畳して起きた場合には, 限界脱線係 数は 0.6 程度となり, フランジ角 $57.5^{\circ}$ の輪軸のそれ に比べても限界は上昇する，反面，その限界を超えた 場合に脱線に至るまでの時間は前述のように大幅に短 縮されると推定される。

周知のことではあるが, このようなフランジ角の増 加は乗り上がり脱線防止の一つの策として極めて有効 である。

$4 \cdot 3$ 短小著大脱線係数の管理 乗り上がり脱線 現象が発生した場合，車輪のフランジ部はレール側面 の接触した点に固着し，あたかもその点に引っ掛かっ たかのような形で，この点を中心に乗り上がる．輪軸 の単位回転角度当たりの車輪乗り上がり量は車軸中心 から前記接触点までの距離に比例するので, 輪軸が同 じ距離を進行する場合には前記の距離が大きいほうが 車輪の乗り上がり量は多くなる(2).

2 章で述べたようにフランジ角が比較的小さい $57.5^{\circ}$ 程度の輪軸が半径 $100 \mathrm{~m}$ の曲線を通過時に車輪 が滑り下がることなくレールに連続的に乗り上がった 場合，乗り上がり開始からわずか $0.4 \mathrm{~m}$ 程度の走行で 脱線に至る。この間を曲線の標準的な制限速度 25 $\mathrm{km} / \mathrm{h}$ 程度で走った場合の所要時間は約 $60 \mathrm{~ms}$ 程度と なる.

乗り上がり脱線防止のためにフランジ角を増加させ たケースを考えてみよう。図 9 はフランジ角が $57.5^{\circ}$, $70.0^{\circ}$ および $87.0^{\circ}$ の円弧踏面, 車輪径 $860 \mathrm{~mm}$ (ただ し, フランジ角 $87.0^{\circ}$ の車輪の径は $500 \mathrm{~mm}$ ) の輪軸が アタック角 $1.3^{\circ}$ で曲線半径 $100 \mathrm{~m}$ の $50 \mathrm{~N}$ レールに 接したとき，車輪踏面のレール踏面からのせり上がり 量と, 車輪中心から接触点位置までの距離の関係を $1 /$ 5 スケールの模型で調べた結果を示す曲線で, 諸元は

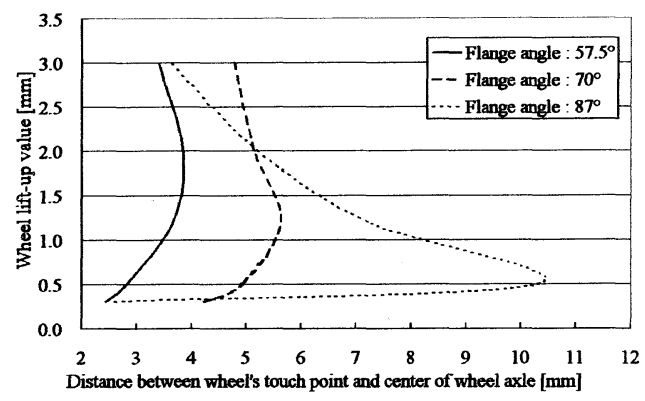

Fig. 9 The relationship between the wheel's contact point position and the wheel lift-up value $(R$ : $100 \mathrm{~m}$, wheel diameter: $860 \mathrm{~mm}$, flange angle: $57.5^{\circ}, 70.0^{\circ}$, wheel diameter: $500 \mathrm{~mm}$, flange angle: $87.0^{\circ}$ ) 
図中に示す ${ }^{(8)}$. 図示のとおり, フランジ角の増大につ れて, 接触点までの距離は増大する傾向にあり, 最近, 多くの鉄道で賞用されつつあるフランジ角 $70^{\circ}$ の輪軸 の車輪中心から接触点までの距離は図示のように $57.5^{\circ}$ のそれに比べおおむね 5 割程度大きい.このこ とは, フランジ角が $70^{\circ}$ 程度の輪軸が乗り上がり脱線 状態になった場合には,「脱線に至るまで距離」はフ ランジ角が $57.5^{\circ}$ の輪軸に比べ大幅に短縮されること を意味する。

近年, 乗り上がり脱線の発生を防止するために，フ ランジ角のより大きい輪軸の使用が好ましい旨の国の 見解が出されている ${ }^{(6)} .4 \cdot 2$ 節で述べたようにナダー ル限界はフランジ角度の増大に応じ上昇するので, 限 界脱線係数を高める観点から見ればこの対策は好まし い.しかし，いったん，臨界状態に陥った輪軸が滑り 下がることなく継続的に乗り上がった場合,「脱線に 至るまで距離」は短くなる。したがって，フランジ角 の大きな輪軸については，このような状況を配慮して 短小著大脱線係数の持続時間の限度をより㛜しく管理 する必要がある。

\section{5. 結 論}

乗り上がり脱線に支配的な影響を及ぼす車輪フラン ジ部とレール側面との摩擦係数 $\mu$ の実態を把握する ために，著者らが提案した手法を用い，1/5スケール の二軸台車を乾燥レール上を低速で走行させることに よって得た $\mu$ は，同じ状態並びにレールおよび車輪の 摩耗金属粉が乾燥レール上に介在した状態で得た同じ 速度域の粘着係数 $\mu^{\prime}$ とほぼ同じ值であり,さらに, 当 該 $\mu^{\prime}$ の值はレールが乾燥状態にある本線上で粘着台 車が $90 \mathrm{~km} / \mathrm{h}$ 程度までの速度域で得た $\mu^{\prime}$ とほぼ同じ 值である事実を踏まえれば, 本線の乾燥レール上の $\mu$ は $\mu^{\prime}$ とほほ同じ程度の值にある可能性が高い. 本研 究で得た $\mu$ に関わるこのような新たな知見に基づい て, 乗り上がり脱線のメカニズムとその防止策につい ての研究を行った結果, 以下のようなことがわかっ た.

（1）直射日光が照射して乾燥状態にあるレール上 で $\mu^{\prime}$ は 0.4 程度に達することを考慮すれば,ナダー ル限界を調べるに際して使用する $\mu$ の值は, 従前から 賞用されている 0.3 程度の值に代えて 0.4 程度の値を 使用することが望ましい.

（2）フランジ角が $57.5^{\circ}$ 程度の輪軸が 8 番片開き 分岐器または半径 $100 \mathrm{~m}$ 程度の曲線上で臨界脱線状 態となってから車輪が継続的に乗り上がった場合, 乗 り上がりを開始してから「脱線に至るまで距離」はわ
ずか $0.4 \mathrm{~m}$ 程度，この間の所要時間は車両が $25 \mathrm{~km} / \mathrm{h}$ 程度で走行した場合にはわずか約 $60 \mathrm{~ms}$ 程度にすぎ ない.

（3）乗り上がり脱線防止のために恷汿(しょうよ う)されている車輪のフランジ角を増加させる対策は 限界脱線係数を高める観点から見た場合の有効性は認 められるが，反面，この対策は「脱線に至るまで距離」 を短縮させる。

（4）前記の（2）および( 3 )項に記載した事実を踏 まえれば，現在は等閑視されている持続時間が短小な ナダール限界を超える脱線係数についても, 曲線半径, 車輪のアタック角およびフランジ角などに応じて多様 に変化する ( 3 ) 項で述べた「脱線に至るまでの距離」 を勘案して，より厳格に管理する必要がある。

本研究の実施に際しては, 当永瀬研究室の研究生牛 若聡, 卒研生木村純一および伊那利晃君など, 多くの 諸君の協力を得た.フランジ角度の大きい実験用輪軸 の製作に際しては JR 北海道のご支援をいただいた。 ここに関係者各位に感謝の意を表す。

\section{文献}

(1) Wakabayashi, Y., Sakahara, H., Hirama, J. and Nagase, K., A Study on Wheel Climb Derailment (2nd Report, Measuring of the Contact Point Position between Rails and Wheels), Trans. JSME, Series $C$, Vol. 67, No. 659 (2001), pp. 2266-2271.

(2) Sato, Y., Hashi, H., Wakabayashi, Y. and Nagase, K., A Study on Wheel Climb Derailment (3rd Report, A Method to Theoretically Calculate the Wheel Lift-up Value), Trans. JSME, Series C, Vol. 73, No. 725 (2007), pp. 59-65.

(3) Hashi, H., Sato, Y. and Nagase, K., A Study on Wheel Climb Derailment (4th Report, Measuring Method on the $\mu$ Value between Rails and Wheels), Trans. JSME, Series C, Vol. 73, No. 732 (2007), pp. 1-7.

(4) Japanese Industrial Standard E 1305, Railway Switches-Shapes and Diamonds (in Japanese), (1998).

(5) Hiroshige, I., Wheel Set (in Japanese), (1971), pp. 278289, Kohyousha.

(6) The Director-General Order of Railway Bureau, No. 148 (in Japanese), devised by the Safety Administrator, (2000-10), the Ministry of Land, Infrastructure and Transportation of Japan.

(7) Hashi, H., Satoh, Y., Hirama, J. and Nagase, K., A Study on Measuring $\mu$ Value under Wheel Climb Derailment (3rd Report, the $\mu$ Value between Rails and Wheels and Possibility of Wheel Climb Derailment Occurrence), The Joint Railway Technology Symposium 'O6, (2006-12), pp. 471-474.

(8) Hashi, H., Hirama, J. and Nagase, K., A Study on Wheel Climb Derailment (Influences of Curvature and Flange Angle on the Contact Position), The Joint Railway Technology Symposium '07, (2007-12), pp. 105-108.

(9) Miyaji, S., Satoh, Y. and Inohana, T., The Derailment Coefficient of a Bolster-less Truck Measured on the 
Wayside and the Car, The Joint Railway Technology Symposium '01, (2001-12), pp. 469-472.

(10) The Investigation Report on the Derailment of Tokyo Fright Terminal Station, ARAIC Report (in Japanese), No. RA 2004-3-1 (2006-6), pp. 9-12.

(11) Onodera, T. and Oogoshi, M., The Relation of Wheel Load Fluctuation to Rail Surface Irregularity, The Joint Railway Technology Symposium '04, (2005-1), pp. 273-274.

(12) Nomura, T., Hirama, J. and Nagase, K., The Influence of Contact Condition between Rails and Wheels upon Track Circuit Shunting (1st Report, Quantitative Evaluation of Factors that cause Inadequate Track Circuit Shunting), Trans. JSME, Series C, Vol. 63, No. 616 (1997), pp. 109-116.

(13) Hashi, H., Sato, Y., Hirama, J. and Nagase, K., Electric Resonance Phenomena of a Truck Circuit Caused by Wheel Sets (The 7th Report, Influence of the Wheel Eccentricity on the Axle Load and the Resonance), The Joint Railway Technology Symposium '07, (200712), pp. 57-60.

(14) The Investigation Report on the Derailment of Takasago Station of Keisei Electric Railways, ARAIC Report (in Japanese), No. RA 2003-3-2 (2004-6), p. 8.

(15) The Investigation Report on the Derailment of Tokyo Metro Hibiya Line (in Japanese), (2000-10), p. 97, the Investigation Committee of the Accident, Ministry of Transportation.

(16) The Director Order of the Engineering Planning Division, No. 42, Railway Bureau (in Japanese), (20056), the Ministry of Land, Infrastructure and Transportation of Japan.

(17) The Investigation Report on the Derailment of Arimaguchi Station of Kobe Electric Railways, ARAIC Report (in Japanese), No. RA 2007-6-2 (20079), p. 6 .
(18) The Investigation Report on the Derailmant of Arimaguchi Station of Kobe Electric Railways, ARAIC Report (in Japanese), No. RA 2007-6-1 (20079), pp. 6-7.

(19) Metro Weekly, Vol. 10, Issue 2 (2007-1), p. 1.

(20) Nagase, K., Sakahara, H. and Nomura, T., A Study on Wheel Climb Derailment (1st Report, Results of Basic Experiments Using Model Truck), Trans. JSME, Series C, Vol. 66, No.652 (2000), pp. 68-75.

(21) Nagase, K., A Study of Adhesion between the Rails and Running Wheels on Main Lines (Results of Investigations by Slipping Adhesion Test Bogie), Proc. IMechE, Vol. 203, No. F 1 (1989), pp. 33-43.

(22) Bowden, F. P. and Taber, D., The Friction and Lubrication of Solids (Trans. into Japanese by N. Soda), (1975), pp. 183-186, Maruzen.

(23) Hayashi, I., Nomura, T. and Nagase, K., Influence of Atmospheric Conditions upon Adhesion between Rails and Wheels, Trans. JSME, Series C, Vol.63, No. 606 (1997), pp. 246-251.

(24) Nagase, K., The State of Adhesion between Rails and Wheels on Main Lines (Results Investigated by the Slipping Adhesion Test Truck), Trans. JSME, Series C, Vol. 54, No. 504 (1988), pp. 1852-1860.

(25) Nagase, K., Wakabayashi, Y., Ohhira, T., Hirama, J. and Tanabe, N., A Study on the Wheel Skidding of JR Ltd Express EMUs (1st Report, Factors Influence upon the Wheel Skidding), Trans. JSME, Series C, Vol.70, No. 689 (2004), pp. 149-157.

(26) Nagase, K., Nakamura, H. and Kobayashi, H., Influence of Weather Condition upon Adhesion between Rails and Running Wheels on Main Lines (Results Investigated on JR Nikko Line by the Slipping Test Truck), Trans. JSME, Series C, Vol. 56, No. 523 (1990), pp. 797-802. 